\title{
MIHALA JANA BORHA DZEJOJUMS „VARAKḶĀNU PILS JŪTU DĀRZS“ (JARDIN SENTIMENTAL DU CHÂTEAU DE WARAKLAND, 1795) APGAISMĪBAS LITERATŪRAS KONTEKSTĀ
}

\author{
Māra GRUDULE \\ Latvijas Universitāte
}

\section{Ievads}

1795. gadā Varšavā franču valodā nāk klajā Mihala Jana Borha (vācu Michael Johann von der Borch-Lubeschitz und Borchhoff, poḷ Michał Jan Borch, 1753-1810) sacerējums Jardin sentimental du château de Warkland. Simonas Sofijas Valkes tulkojumā un Māra Salēja lieliskā atdzejojumā to ir iespējams lasīt arī latviski ${ }^{1}$ — „Varakḷānu pils jūtu dārzs“ 2019. gadā franču oriǵinālā un tulkojumā ir publicēts ar Latvijas Nacionālās bibliotēkas projekta „Neredzamā bibliotēka“ finansiālu atbalstu. Nelielais, pat pirmajā acu uzmetienā - necilais - kabatas formāta izdevums iemieso pagāiuša, bet aizraujoša laikmeta pēdas (Borch 2019).

Pēc 1790. gada, atgriezies no Eiropas celiojumiem, un iespējams, arī saguris no diplomātiskajām spēlēm, Borhs apmetas uz pastāvīgu dzīvi Varaklānu pilī un kopā ar itālu arhitektu Vinčenco de Macotti (Vincenzo de Mazotti, 1756-1798) turpina darbu pie savas pils un parka iekārtojuma. Borha dzejojums un ieceres realizācija Varakḷānos gan ir divas atškirīgas pasaules. Dzejojums, kā pats autors atzīst, ir ,alegorija“ (Borch 2019: 15), kurā plašais ūdens klajs pils priekšā ir „cilvēka dzīves okeāns“ (Borch 2019: 15), un no šîs vietas sākas arī ceḷojums , jūtu dārzā“.

Mihals Jans Borhs, Polijas Lietuvas galma aprindām pietuvināts labi izglītots dabaspētnieks, celatotājs un diplomāts, ir mazliet arī dzejnieks. Viņa „Varakḷānu pils jūtu dārzu“ mēdz dēvēt par labāko, ko Borhs ir sacerējis. To iespējams uzlūkot kā ceḷvedi pastaigā pa parku. Kamēr Borha varonis jaunais aristokrāts (sic! Franču revolūcijas vēsmas viņu nav skārušas) mēro ceḷu no viena parka objekta līdz nākamajam, stāsts rit rāmā prozas valodā, savukārt vēstījumi uz tajā izvietotajām plāksnēm, blukiem, mūriem un citiem objektiem ir lasāmi dzejā, tie veido galveno un garāko sacerējuma dalıu. Tie

2019. gada sākumā publicēts vēl viens Borha dzejojuma tulkojums (Borhs 2019: 60-75). Salēja un Jēkabsones-Valteres latviskojumu salīdzinājums sniedz labu priekšstatu par to, kāda nozīme ir dzejnieka talantam un kāda - tulkojuma precizitātei. 
aicina izskaust sevī netikumus un cildina morālās vērtības un kalpošanu vispārējam labumam, tēvzemei un nācijas interesēm kā augstāko tikumu.

\section{Libertīnu romāni un moralizējošā literatūra}

Gandrīz vienlaikus ar Mihala Jana Borha sacerējumu Francijā nāk klajā libertīna marḳiza de Sada (Donatien Alphonse François, Marquis de Sade, 1740-1814) romāns ,Justīne jeb tikumības nedienas“ (Justine ou Les Malheurs de la vertu, 1791²). Dažā ziņā arī to var uzlūkot kā ,jūtu dārzu“. Ar galvenās varones Justīnes, romānā arī - Terēzes, starpniecību de Sads izvadā lasītāju cauri dažādām izvirtušu vīru seksuālo org̣iju epizodēm pilīs, pilsoniskos namos un klosteros, atklājot miesas kaislību bezdibeņus, kas nereti augstāko punktu sasniedz savu upuru baisāko ciešanu brǐžos. Romāna sižetu veido Justīnes cel̦š no vienas epizodes līdz nākamajai. Atškirīībā no apgaismības laikmeta libertīnu romānu vairuma, kuru darbība risinās urbānā vidē, de Sads liek savai varonei galvenokārt klīst pa mežiem, laukiem un plavām. Visbiežāk nejauša noklīšana no ceḷa, apmaldīšanās biezoknī un nakšņošana zem krūmiem, slēptiem gāiēju acīm, ir iemesls tam, lai nokḷūtu kārtējo mocītāju rokās. Mežs un biezoknis, citiem vārdiem - nekultivētā vide, labi sasaucas ar libertīnu neapvaldītajām kaislībām. Antropologs Tomas Vīns libertīnu romānus raksturo kā ,savdabīgu audzināšanas romāna formu, kurā jaunais varonis vai varone tiek iepazīstināti ar pasaules realitāti. Šì galvenokārt ir erotiska rakstura izglīî̄ba“, atzīst Vīns, ,viena no 18. gadsimta atslēgas mācībām par seksuālo baudu kā prāta un ķ̣ermeņa atbrīvotāju“ (Wynn 2011: $416)^{3}$. Borha un de Sada gandrīz vienlaikus tapušie darbi atklāj apgaismības literatūras divas puses. Tajā libertīnu romāni un morālistu sacerējumi veido pretstatu pāri, tomēr kā viens tā otrs - kā brālis un māsa pieder jaunajai laikmetīgajai literatūrai. Tie kopā rada jaunu domas un rakstniecības veidu, kas iemieso galvenokārt sekulāru skatīijumu uz cilvēka dabu un viņa morālo dzīvi (Méchoulain 2017: 229).

Borha sacerējums gan liecina, ka arī viñam pašam cilvēciskās kaislības nav svešas. Bet Borhs ir estēts. „Varakḷānu pils jūtu dārza“ sākumdạ̣ā autors pārlūko mākslas darbus, kuros attēlotas grieķu un romiešu mītu epizodes.

2 Arī de Sada romāns lasāms latviski: Marķīzs de Sads. Justīne jeb tikumības nedienas. A. Skrābanes tulkojums. Rīga: Jumava, 2007.

3 [..] the libertine novel takes the form of the Bildungsroman, whereby the young hero or heroine is educated to the realities of the world. This education is primarly of an erotic nature, and it is one of the 18th' century key lessons that sexual pleasure, devoid of the stain of sin, can liberate the mind as well as body. 
Aiz dailo mākslu un tajās ietverto mītu plīvura slēpjas incests brāla un māsas, un tēva un meitas starpā, pavešana, izvarošana un ārpus laulības sakari. Tie attēloti apgaismības laikmeta izglìtotajam lasītājam labi zināmos Rubensa, Ticiāna, Korredžo, Rembranta, Delvo, Rīlanda un citu mākslinieku darbos. Tā, piemēram, Borhs raksta: „Ar meitu Kinirs laižas pretdabiskā dēkā, / Par to, ka savu meitu glāsta, aizmirstot" (Borch 2019: 9), kā zināms, Kinira sakars ar savu meitu Mīru beidzas ar viņas pārvēršanu par koku un Adonīsa piedzimšanu. Šo epizodi savā gleznā 1690. gadā izmantojis itāḷu baroka meistars Markanto Fransešīni savā gleznā. Savukārt Borha pieminētā Lapitu valdnieka Îksona iekāre pret dievu sūtīto viltus Hēru jeb Junonu un Semeles nāve, ieraugot Jupiteru (Borch 2019: 7-9), skatāmas Rubensa gleznās; Ledas un Zeva jeb gulbja motīvs (Borch 2019: 9), no kura vinai piedzimst divi bērni, atklāts Borha laikabiedra iepriekš minētā Viljama Vīna Rīlanda gravīrā. Borha pieminētā Biblīda, ,kas krīt ar brāli asinsgrēkā“ (Borch 2019: 9), iedegas kaislē pret savu dvīṇu brāli Kauno. Biblīda un Kauno ir attēloti apgaismības laikmeta mākslinieka iepriekš minētā Lorensa Delvo figurālajā veidojumā. Borha pieminēto Pomonu (Borch 2019: 9) paved viņas topošais vīrs, tuvojoties tai kā siena plāivējs un kā gans, kā abolu lasītājs un karavīrs, kā zvejnieks un veca sieva, tas vēršas par vīnogu šḳēēēm Pomonas rokās un galu galā viņu arī iegūst. Atsauce uz šo mītu skatāma Dāvida Teņjēra Vecākā gleznā „Vertumns un Pomona““4.

Tomēr kavēties pie kaislību tēlojuma, nav Borha mērķis: „Vai dievus netikḷus, kas vilt un krāpties prot, / Par labu paraugu mums nāktos uzlūkot? [..] Vai māksla blāvāka, ja tajā tikumiem / Ar veiklu kaltu mākslinieks prot godu dot?“ (Borch 2019: 9). Piesaucot kara dievu un trīs dūšīgus romiešus, kas bijuši gatavi ziedot savu dzīvību par tēviju - un „tēvija“ būs atslēgas vārds arī dzejojuma beigās - Borhs noslēdz atskatu pagātnē un vedina lasītāju doties „,ārzā vienkāršā, ko daba apglezno“ (Borch 2019: 11).

\section{Jauna aristokrāta rokasgrāmata}

„Varakḷānu pils jūtu dārza“ sižets vijas ap pastaigu. Kā raksta vācu literatūrzinātniece Ulrike Plāta: „,18. gadsimta otrajā pusē pie vispār atzītākajām pasaules iepazī̌anas formām piederēja tieši ķermeniska un jutekliska apkārtējās vides pieredze, kas iegūta, uzturoties dabā. Ja iepriekšējos laikos celojuma mērksis bija izglīîibas centri vai izslavēts meistars, tad ap 1800. gadu ceḷš līdz mērksim un kustība vidē pati par sevi bija daḷa no kognitīvā mācību

4 Visi iepriekš minētie mākslas darbi bez pūlēm atrodami tīmeklī. 
procesa. [..] cel̦ojuma literatūras autoram bija jābūt sinestēzistam, gleznojot un komponējot ainavu ar vārdiem“ (Plath 2011: 78, 80)5. Arī Borhs liek savam jaunajam aristokrātam un ar viņa starpniecību - arī lasītājam redzēt, saklausīt un izdzirdēt pasauli - to atklāt ar visām maņām. Tomēr dzirdes, redzes un ožas kairinājums kalpo tikai kā atgādne par bīstamību, ko sevī slēpi jutekḷi. Kaislība nomāc prātu un iemidzina tikumus. Borhs raksta: ,jauneklis iestumj laivu uz baudu salas pusi [..] ūdeņi ar maǵisku atbalsi dubulto tās valdzinājumu [..] salda smarža apņem, rozes, savijušās ar jasmīniem un sausseržiem, tūkstošiem ziedu nosēts zāliens, jaunā ceḷotāja maņas tiek maigi kairinātas — rezēda un smaržīgā vanila [..] aicina l̦auties baudai““ (Borch 2019: 19, 21). Tas viss ved maldu ceḷos. No kāda ziedu groza izlien čūska, baudkāras sievas acu skatiens ir miegains, blāvs un garlaikots, jaunais varonis nepatikā novēršas.

Viss turpmākais ceḷš ir veltīts mācībām no uzrakstiem uz ceḷā aplūkotajiem pīlāriem, lapenēm, templiem, drupām, marmora bluķiem, kolonnām, eremīta būdas sienas, antīka portāla, piemineklạ, piramīdas, plāksnes un tā joprojām. Pretī kaislībai tiek likta mīla laulībā, cieņa un gods, pretī mizantropijai, paštaisnumam un skaudībai - draudzība un tikumība, pretī depresīvām nāves domām - ticība mūžīgai gaismai. Augstā stila rindas papildina laba deva teatrālisma un eksaltācijas. Borhs liek savam varonim „mesties ceḷos“ (Borch 2019: 49), „pilnam bijības lūgties“ (Borch 2019: 49), ,,dot zvērestus“ (Borch 2019: 59) un „sildīt krūtīs paklausības, cieņas uzticības, aizrautības un pakḷāvības jūtas“ (Borch 2019: 59). Jaunais aristokrāts ceḷojumu noslēdz pie Tikuma un Slavas templịem ar piemiņas zīmēm vietvaldim Vidzemes generālgubernatoram un vienlaikus arī Borha sievastēvam Georgam fon Braunam (Georg Reichsgraf von Browne, 1698-1792) un Krievijas carienei Katrīnai II Lielajai (Ekaterina II Velikaja, 1729-1796), viņas dēlam Pāvelam Petrovičam (Pavel I Petrovič Romanov, 1754-1801) un vedeklai Marijai Fjodorovnai (Marija Fedorovna, 1759-1828). ,Jo tikumu tikums ir nesavtīga ziedošanas vēlme nācijas kopējām interesēm un tiem, kas ir nomodā par šīs cēlās un varenās impērijas labklājību“ (Borch 2019: 61), raksta Borhs. Patoss sasniedz augstāko pakāpi un tā piederas, tāda ir laikmeta mode. Salīdzinājumam — kad 1782. gada novembrī Rīgā viesojas iepriekš minētie

5 In der zweiten Hälfte des 18. Jahrhunderts gehörten direkte körperliche und sinnliche Umwelterfahrungen, gesammelt bei Aufenthalten in der Natur, zu den allgemein beliebten Formen der Weltaneignung. (..) Während in früheren Zeiten die Ausbildungsstätten oder Meister das Ziel der Wanderschaft waren, wurden um 1800 der Weg zum Ziel und die Bewegung in der Umwelt zu einem Teil des kognitiven Lernprozesses. (..) Die Reiseschriftsteller hatte Synästhesist zu sein, hatte Landschaften mit seinen Worten zu malen und zu komponieren. 
Pāvels Petrovičs un Marija Fjodorovna, Borha sievastēvs reihsgrāfs fon Brauns sarīko viesiem cien̄̄gu uzņemšanu: Klīversalā tiek celti goda vārti, pie Rīgas rātsnama ir novietota goda kolonna, savukārt gீenerālgubernatora pils priekšā īpaši šim svinīgajam gadījumam ir izveidots Goda templis, balstīts uz korintiešu kolonnām, apvìts ar ziedu vītnēm un izgaismots. Tā vidū ir Prieka altāris. Virs altāra laistās ugunīgi vārdi: „Pāvels Petrovičs“ un „Marija Fjodorovna“, tos papildina vizulojojošs uzraksts dzejā. Blakus altārim ir izvietotas Minervas un Cerības statujas, templa ieeju grezno Tikuma, Mīlestības, Pastāvības un Pilnības vāzes un Cēzara, Augusta, Tita Flāvija Vespasiāna, Titus, Marka Aurēlija un Konstantīna krūšutēli. Vakarā, protams, ir sarīkota ugunošana. Kā raksta Rīgas vācu avīze, „gavilējošais [ḷaužu] pulks ar laimes vēlējumiem sāka svinēt mūsu prieka dienas svētkus“ (Anon. 1782: 8) ${ }^{6}$.

\section{4. „Varakḷānu pils jūtu dārza“" konteksti: dārzkopība}

18. gadsimta otrajā pusē Eiropas dārzu un parku kultūrā notiek pāreja no franču barokāli simetriskajiem dārziem uz angḷu ainavu parkiem. Žana Žaka Ruso (Jean Jacques Rousseau, 1712-1778) idejās ieklausīiies, apgaismotais cilvēks mācās saskatīt skaisto dabiskajā, upes ielokos, pḷavu un mežu ainavās, ezeru salās un pakalnos savas pils vai muižas apkārtnē. Saplūst jēdzieni „ainava“ un „dārzs“, izveidojas jauns profesionāḷa apzīmējums — „ainavu dārznieks“. Izglītotajam piederas ne tikai grāmatu, mākslas darbu, minerālu, putnu ādiṇu un izbāzeņu krāšana, kas vienlaikus ceḷ arī to īpašnieka prestižu, bet parku un stādījumu iekopšana. Itālijas ceḷojumiem nākot modē, dārzkopībā dominē t. s. Augusta stils - Romas imperatora Augusta laikmetam (27.-14. p. m. è.) raksturīgā klasiskā ainava ar statujām, grotām, tempḷiem, tiltiem ar pārsedzēm un jumtiniem, iedvesmu gūstot no renesanses arhitekta Andrea Palladio (Andrea Palladio, 1508-1580), grieķu un romiešu kultūras cienītāja, darbiem. Dabā izvietotie arhitektūras objekti, kurus 18. gadsimta otrās puses dārzkopības literatūrā dēvē par fabriqué jeb 'cilvēka roku darinājumiem', stāsta par pagātni, par svešzemju kultūru, vēsturi, mākslu, rada asociācijas un sniedz garīgu baudu, papildinot pastaigas prieku. Dabisko ainavas skaistumu iemieso arī zemnieku saimniecības un tām piederīgās ganības, šķūni, klētis un dzirnavas. Ķīles universitātes profesors Kristiāns Kejs Lorencs Hiršfelds (Christian Cay Lorenz Hirschfeldt, 1742-1792) publicē dārzu dizaina teoriju piecos sējumos Theorie der Gartenkunst (1779-1785), iesakot

6 [..] die frohlockende Menge die Feyer unserer Freudentage unter Segenswünschen begieng. 
vāciešiem, iedvesmojoties no franču baroka dārza un angḷ ainavu parka, radīt pašiem savu - vācisko dārzu (Kluckert 2000: 406). Ja Anglijā baroka dārzus kā novecojušus un laikmeta modei neatbilstošus posta, tad vācu zemēs tos uzlabo un modernizē (Turner 2011: 294-295). Hiršfelds augstu vērtē angḷu emocionālo dārzu, norādot, ka dārzs nav domāts tikai acu priekam, bet tas arī rosina fantāziju ar savu vērienu, melanholijas, prieka un cēlā izjūtu. Parks piedāvā iespējas sentimentālai jūsmai - temp̣̣i un memoriāli ar uzrakstiem svin draudzību, mīlestîbu, uzupurēšanos, dzirnavas, ganībām atvēlētās pḷavas, šķūn̄̄ši un zemnieku mājas idealizē lauku dzīvi, iedveš mieru un harmoniju (pēc Benn 1991: 13). Starp citu, Baltijas kultūrvēsturnieks Johans Kristofs Broce (Johann Christoph Brotze, 1742-1823) Inčukalna muižā 1801. gadā ir atradis pieminekli Hiršfeldam un to uzzīmējis, pievienojot arī uz tā lasāmo uzrakstu: „Hiršfelda pieminai 1799. gada 24. jūnijā. Šajā parkā, kuru pa pusei radīja fantāzija, pa pusei daba, kur zalıas ēnas savienojas ar strauta čalošanu, lai pie Hiršfelda pieminekla lauku dabas draugam nekad netrūktu dvēseles miera, ko viņš mums mācīja meklēt un baudīt klusā vietā“" (Broce 2002: 133). Līdzīgi kā Borha sacerējumā, arī šajā paīsajā vēstījumā uzmanība veltīta gan maņu - redzes un dzirdes - vingrināšanai, gan refleksijai: Broces zīmējumā redzams arī sūnu un velēnu sols atpūtai un pārdomām.

Ang̣̣u ainavu dārza tradīcija 18. gadsimta otrajā pusē nostiprinās arī Polijā ar Sīmona Bogumila Cuga (Szymon Bogumil Zug, 1733-1807), viena no lielākajiem apgaismības arhitektiem, starpniecību. Par anglu dārziem kā Vidzemē vispopulārāko dārza veidu raksta Heinrihs Johans fon Jannavs (Heinrich Johann von Jannau, 1753-1821; Jannau 1781: 65), tos slavē arī Augusts Vilhelms Hūpels (August Wilhelm Hupel, 1737-1819) savā „Ekonomiskajā rokasgrāmatā“" (Hupel 1796: 256). Prasmīgi iekoptu dārzu vai muižas parku var salīdzināt ar atvērtu grāmatu, ar enciklopēdiju vai pat ar veselu bibliotēku - katra jauna objekta iepazīšana un uzrakstu lasǐšana līdzinās lapas pāršķiršanai, tempḷi ir papildināti ar citātiem, kolonnas - ar norādēm, piemiņas akmeņi - ar dzejoḷiem.

Baltijā 18. gadsimta otrajā pusē pārejas posmu no baroka dārza uz ainavu parku labi raksturo t. s. izpriecu mežiņi ar celiņiem pastaigām, kuru krustpunktos novietoti obeliski, stēlas, vāzes, urnas ar soliņiem meditācijai. Šāds mežiņš ir bijis Bīriņos, domājams arī Drustos, Ulbrokā, Jāņmuižā pie Cēsīm un citur. Kādā Karla Gotharda Grasa (Karl Gotthard Graß, 1767-1814) zīmējumā ir redzama birzīte Strazdumuižā, t. s. Dorotejas līksme ${ }^{7}$. 1791. gadā

7 Dorotejas līksmes, orig̣inālā Dorotheens Lust nosaukums cēlies no tā brīža muižas īpašnieka atraitnes Dorotejas fon Fromholdes vārda. 
tajā ir atradies piemineklis, uz kura četriem sāniem bijuši uzraksti vāciski, latviešu tulkojumā uzraksti vēstītu: „Pēc sava drauga / aicinājuma šeit / brālīgi rokās sadevās / daba un māksla“; „Draudzība šo vietu / lēma tīkamam laika kavēklim / un nosauca to par Dorotejas līksmi“; „Lai sveicināts ikviens, / kas ar prātu bauda un / nevis postot traucē / vēlā svētceḷnieka priekus“ un „Prātīgam priekam, / sirsnīgai draudzībai, / pašapcerei vienatn̄̄“ (Broce 1996: 129). Nezināmais autors ir izmantojis tos pašus atslēgas vārdus, kurus atrodam arī Borha sacerējumā.

Jauku liecību par Kurzemes parkiem Meženieku, Vormsātu, Izriedes, Lielbērzes un Virkus muižās, ar un bez apskates objektiem un ainavu lieliski greznojošām zemnieku saimniecībām devis Baltijas vācu dzejnieks Ulrihs fon Šlipenbahs (Ulrich von Schlippenbach, 1744-1826) darbā „Gleznieciski ceḷojumi Kurzemē“ (Schlippenbach 1809). Tātad Borha laikā ne Kurzemē, ne Vidzemē nav trūcis muižiņu, kuru apkārtnē bijušas mākslīgas pilsdrupas, vientuḷnieku namiņi, urnas, obeliski, romantiskas grotas, piramīdas un tempḷi un pamazām šì mode sasniegusi arī Latgali. Lielu ainavu parku Vidzemes ziemeḷdaḷā - Alūksnē no 1795. līdz 1830. gadam iekārto Kristofs Burkards fon Fītinghofs-Šēls (Christoph Burkard von Vietinghoff-Scheel, 1767-1829), izmantojot tam l̦oti pateicīgo reljefu - pakalnus, ezeru un salas. Kā norāda mākslas vēsturnieks Ojārs Spārītis, „Alūksnes parka ansamblis [..] sniedz visplašāko mitolog̣ijas, alegoriju un personifikāciju diapazonu Latvijas parku mākslā“ (Spārītis 1998: 29). Tā radīšanas laikā parkā bijusi oranžērija ar skulptūrām, Saules templis kā rezonators ar vēja dievam Aiolam veltītu aprīkojumu melanholiska rakstura skaņu ienesumam, Dianas skulptūra uz postamenta, Pomonas templis, ķiniešu paviljons, obelisks, paviljons ar piramidālu jumtu Krievijas caram Aleksandram I un citi objekti (Spārītis 1998: 28, 41).

\section{Mihals Jans Borhs, iespējamie ietekmju avoti un atskaņas}

Šodien neiespējami pateikt, no kā tieši Mihals Jans Borhs, radot savu sacerējumu par Varakḷannu pils jūtu dārzu, ir ietekmējies. Viņš ir cēlies no Baltijas vācu dzimtas, tomēr dzīves laikā sevi pozicionējis kā poli un krietnu dzīves sprīdi pavadīịis Polijas - Lietuvas lielvalsts galmā, dzīvojis Varšavā, bet viesojies Saksijā, Šveicē, Francijā, Sicīlijā un Maltā, Holandē un Lielbritānijā, un visbeidzot atgriezies Varakḷānos. Ikdienā grāfs Borhs sazinājies un rakstīijs poliski, vāciski, apguvis angḷu un itāḷu valodu, dzejojis franciski, itāliski un nedaudz arī - latviski (Taimiņa 2013: 6). Kā atzīst kultūrvēsturnieks Kaspars Klaviņš: „,Borhu dzimtā patriotisms ir daudzpakāpju pārreǵionāls 
jēdziens, orientējoties pēc Eiropas vērtību skalas [..] Borhs bija ārkārtīgi veikls diplomāts, apveltīts ar labu intuīciju un spēju sasniegt iecerēto mērķi, par spīti jebkuriem šksēršliem, neatpaliekot no sava laika ironiskajiem franču un itāḷ avantūristiem, kas noteica izturēšanās stilu 18. gadsimta II puses Eiropā“ (Kḷaviņš 2013: 89). Poḷu mākslas zinātniece Jolanta Polanovska (Polanowska) Varakḷānu pils faktiskajā dārzā un Borha dzejojumā saskata ietekmes no angḷu kultūras - no Stovas (Stowe) ainavu parka Bekingemšīrā (Buckinghamshire). Tas 18. gadsimta otrajā pusē ir bijis viens no populārākajiem pastaigu mērkiiem Eiropā. 1754. gadā Stovu apmeklējis arī vēlākais Mihala Jana Borha paziņa Polijas karalis Staņislavs Augusts Poņatovskis (Stanisław August Poniatowski, 1732-1798) (Polanowska 2013). Starp citu, arī Stovas īpašnieks Ričards Templs (Richard Temple, 1675-1749) parka apskatei ir izstrādājis ceḷvedi, tomēr atšksirībā no Borha, tikai īsi informējot par parkā redzamajiem objektiem un iztiekot bez poētiskiem papildinājumiem un alegorijām (Temple 1751). Polanovska līdzības saskata gan Borha pils un Stovas pils parka izvietojumā, gan Varaklạnos plānotajā, gan Stovā izvietotajā tempḷu skaitā - pieci un astoņi, gan abiem parkiem raksturīgajā eremīta namiņā, gan nacionālu varoṇu godināšanā - Borha poēmas sākotnējā iecerē tie ir izcili poḷi, laikmeta vēsmām mainoties - poēmas gala variantā Krievijas valdniece Katrīna Lielā un viņas g̊imenes locekḷi. Gan Stovā, gan Borha pils parka dziļumos ir piramīdas, kas godina arhitektu piemiņu. Abos parkos ir arī pieminekḷi pils īpašnieku suņiem. Tomēr jāatzīst, ka visi iepriekšminētie ir arī tradicionāli šā laikmeta kultūras objekti. Tikpat labi var saskatīt līdzību starp Borha cildinājumu Georgam fon Braunam un uzrakstu uz obeliska fon Fītinghofam Alūksnes parkā, vai starp dzejojumā pieminēto apbedījumu vietu — „hieroglifiem klātu piramīdu“ (Borch 2019: 41) ar „pazemes velvēm ar nišām“ (Borch 2019: 41) un mākslas vēsturnieka Imanta Lancmaņa aprakstītajām kapenēm Dunalkā - piramīdas formā ar cilindrisku telpu, kuras mūros trīs rindās likts pa 14 radiālām nišām zārku novietošanai. Mūsdienās no tā visa ir saglabājušās drupas (Lancmanis 1998: 54).

Iespējams, Borhs patiešām ir iedvesmojies no Stovas, lai gan nav ziņu, vai viņš tur vispār ir bijis. Nav arī neiespējams, ka ceḷojums cauri Varakḷānu pils fantāzijas parkam ir dažādu iespaidu un Borha paša radīto priekšstatu veidots, iedvesmu gūstot no ārzemēs redzētā.

Sentimentālā un t. s. izpriecu dārza mode 19. gadsimtā pamazām zaudē savu lomu kā nedabiska un ārišķ̄ịa (Benn 1991: 13-14). Tomēr no Borha laikmeta - no 18. gadsimta beigām līdz mūsu dienām — vienā otrā Latvijas muižas parkā kaut kas ir vēl saglabāiies: joprojām iespējams apskatīt mākslīgās pilsdrupas un eremītu lūgšanu kapelu Jumpravmuižā. Un noteikti ir vērts 
doties uz Alūksni, lai iepazītu turienes plašo ainavu parku ar fon Fītinghofu sarūpētajām mazajām arhitektūras formām. Apskatei ir atvērta arī pati Varaḳ̣ānu pils. Iespējams, tur gūtais iespaids būs vēl spēcīgāks pēc Mihala Jana Borha „Varakḹanu pils jūtu dārza“ lasīšanas.

\section{Literatūra}

Anon. 1782.

Benn, Sheila Margaret. 1991.

Borch, Michal Jan. Borhs, Mihals Jans. 2019.

Borhs, Mihals Jans. 2019.

Broce, Johans Kristofs. 1996.

Broce, Johans Kristofs. 2002.

Hupel, August Wilhelm. 1796.

Jannau, Heinrich Johann. 1781.

Klaviņš, Kaspars. 2013.

Kluckert, Ehrenfried. 2000. Lancmanis, Imants. 1998.

Méchoulain, Eric. 2017.

Plath, Ulrike. 2011.

Polanowska, Jolanta. 2013.

Schlippenbach, Ulrich von. 1809.
Vermischte Nachrichten. Rigische Anzeigen 47. 21. Nov.

Pre-Romantic Attitude to Landscape in the Writings of Friedrich Schiller. Berlin, New York: W. De Gruyter.

Jardin sentimental du château de Warkland. Varaklānu pils jūtu dārzs. Tulkojuši Māris Salējs un Simona Sofija Valke. Rīga: Latvijas Nacionālā bibliotēka.

Varaklānu pils sentimentālais dārzs, Borhu grāfistē Baltkrievijā. Tulkojusi Valda Jēkabsone-Valtere. Kultūrainava: tās saturs, uztvere un transformācijas. Dārzu un parku kultūra Baltijas valstīs un Eiropā. Rīga: Medicīnas apgāds, 60-75.

Zìmējumi un apraksti. 2. sēj. Rīga: Zinātne.

Zīmējumi un apraksti. 3. sēj. Rīga: Zinātne.

Oekonomisches Handbuch für Lief- und Ehstländische Gutsherren wie auch für deren Disponenten. Erster Theil. Riga: J. F. Hartknoch.

Sitten und Zeit: ein Memorial an Lief- und Estlands Väter. Riga: J. F. Hartknoch.

Mihaela Johana Borha tikšanās ar Voltēru - Latvijas kultūras vēstures eiropeiskā lappuse. Latvijas Vēstures Institūta Žurnāls 4. 80-97.

European Garden Design, Cologne: Könemann.

Iznīcības simboli un romantisms. Grosmane, Elita (sast.). Romantisms un neoromantisms Latvijas mākssā. Rīga: Izdevniecība AGB, 42-61.

From Moralists to Libertines. C.Prendergast (ed.). A History of Modern French Literature from the sixteenth century to the twentieth century. Princeton University Press, 229-249.

Sinneslandschaften. Die Bedeutung der Sinne bei der Beschreibung baltischer Landschaften und Kulturen (1750-1850). L. Lukas, U. Plath, K. Tüür, J. Undusk (Hrsg.). Umweltphilosophie und Landschaftsdenken im baltischen Kulturraum. Tallinn: Underi ja Tuglase Kirjanduskeskus, 74-109.

Michal Jan Borch and his rezidence in Varaklāni. Mākslas Vēsture un Teorija 16. 18-32.

Malerische Wanderungen durch Kurland. Riga und Leipzig: C. J. G. Hartmann. 
Spārītis, Ojārs. 1998.

Taimiņa, Aija. 2013.

Temple, Richard. 1751.

Turner, Tom. 2011.

Wynn, Thomas. 2011.
Romantisma tēlu sistēmas semantika Latvijas muižu parku arhitektūrā un tēlniecībā. E. Grosmane (sast.). Romantisms un neoromantisms Latvijas mākslāa. Rīga: Izdevniecība AGB, 28-41.

Borchiana versus Siciliana. Grāfa Borha Sicīlijas ceḷojums un tā reminiscences. Mākslas Vèsture un Teorija 16. 5-17.

Stow: The gardens of the Right Honourable the Viscount Cobham. Buckingham: B. Seeley.

European Gardens. History, Philosophy and Design. London, New York: Routledge.

Libertinage. W. Burgwinkle, N. Hammond, E. Wilson (eds.). The Cambridge History of French Literature. Cambridge: Cambridge University Press, 412-419.

\author{
Māra Grudule \\ Latvistikas un baltistikas nodala \\ Humanitāro zinātņu fakultāte \\ Latvijas Universitäte \\ Visvalža iela 4a, Rīga, Latvija \\ mara.grudule@latnet.lv
}

\title{
SUMMARY
}

\section{Jardin sentimental du château de Warkland (1795) by Michał Jan Borch in the Contexts of Enlightenment Literature}

\author{
Māra GRUDULE
}

The article provides an insight into the literary and cultural-historical contexts of Michał Jan Borch's poem Jardin sentimental du château de Warkland, published in Warsaw in 1795. Borch's poem enters the literary space almost simultaneously with the most remarkable libertine novel by Marquis de Sade Justine ou Les Malheurs de la vertu (1791). Both texts, although opposite in content - one emphasizes the need to cultivate virtues, the other reveals the most unattractive aspects of human nature - reflect the Enlightenment's interest in the inner world of a man - desires, passions and moral virtues. The chosen study method a thematic walk in nature from one instructive sculptural object to the next - corresponds to Enlightenment didactics - knowledge can be acquired by moving in nature, through physical and sensual adventures, as well as reflecting on the objects seen on the way. Pathos-filled style commemorating political figures echoes the ambitious enunciations in the Baltic press about the anniversaries and visits of European rulers. The description of the garden of Borch's Varaklāni castle reflects a characteristic passion for the creation of gardens and landscape parks: the garden enchanted by the author's fantasy corresponds to the model of gardens and landscape parks all over Europe, including the Baltic, at the turn of the 18th and 19th centuries, e.g. the Stowe Garden in England, the landscape garden around Alūksne castle in Vidzeme, and the Meženieki, Vormsāti, and Izriede palace gardens in Kurzeme. 